\title{
A Fotografia como ferramenta de Ensino e Divulgação Científica
}

\section{Carlos Eduardo Belz}

Laboratório de Ecologia Aplicada e Bioinvasões (LEBIO), Centro de Estudos do Mar (CEM), Universidade Federal do Paraná (UFPR), Pontal do Paraná, Paraná, Brasil

Correspondencia: belzoceanos@gmail.com

É inegável a contribuição da imagem para a sociedade humana. Desde a préhistória, o homem procurou representar as suas relações sociais e com o ambiente por meio de imagens. Mas somente em 1839 foi possível fixar uma imagem em um processo fotográfico (Hacking, 2012). Desde então a fotografia passou por vários momentos. Foi considerada de segunda importância no início, mergulhada em uma comparação com as demais artes visuais e foi ganhando cada vez mais importância com a popularização dos meios de registro fotográfico, até chegar aos dias atuais como um fenômeno de comunicação (Borges, 2003).

Não podemos esquecer que a fotografia é uma forma de comunicação. O próprio nome já carrega o sufixo "grafia”, do Grego "escrita”, uma referência clara ao caráter comunicativo da imagem. Assim como a tinta é o material com o qual materializamos a escrita, na fotografia a luz é o elemento que permite a comunicação. Porém, uma discussão permanente trata da dualidade da interpretação da imagem fotográfica. Seria ela uma simples representação da realidade ou por meio da linguagem fotográfica podemos mudar a forma de enxergar a realidade? Segundo Hacking (2012), a fotografia pertence tanto à esfera da realidade quanto à da imaginação. Embora por vezes favoreça uma em detrimento da outra, ela nunca abre mão de nenhuma das duas completamente. 
É justamente esta complexidade da imagem fotográfica que a popularizou na idade moderna. A ponto de ela influenciar de forma direta no cotidiano das pessoas, nos caminhos políticos da sociedade, no desenvolvimento tecnológico e científico e em várias outras áreas, registrando e ao mesmo tempo transformando a realidade que vivemos (Sontag, 1986).

Nos dias atuais, o fácil acesso e a banalização da fotografia geram uma avalanche de imagens que muitas vezes não trazem um contexto comunicativo atraente. Para que uma imagem seja atraente ela precisa estar carregada de um contexto comunicativo mais complexo, podendo incitar uma análise e interpretação também mais complexas.

É neste contexto que a fotografia pode ser utilizada como uma importante ferramenta de comunicação científica e de ensino em qualquer área das ciências. $\mathrm{O}$ registro da realidade e ao mesmo tempo a linguagem fotográfica que inspira muitas interpretações da realidade, podem ser utilizadas no campo da física, da química, da história, da geografia, da sociologia, da biologia e de quase todas as áreas do conhecimento. Porém esta fotografia científica não pode ser encarada como algo complexo e demasiadamente técnico. A mesma fotografia de uma paisagem, que na mão de um turista é apenas um belo registro, na mão de um geógrafo ou de um professor pode ter uma série de aplicações científicas. Portanto, a fotografia científica não é nada mais do que uma fotografia utilizada como objeto de pesquisa, de divulgação científica ou de ensino. Porém é evidente que produzida com o conhecimento técnico de alguém de uma determinada área, ela passa a ter uma maior amplitude de interpretações. Ao mesmo tempo, sendo registrada com conhecimento sobre a técnica e a linguagem fotográfica, ganha em capacidade comunicativa.

Enquanto a popularização da fotografia trouxe consigo uma banalização da imagem, ela também oferece, nos dias de hoje, grande número de possibilidades de utilização da imagem como ferramenta de trabalho. O crescente avanço da ciência carrega junto com ela a necessidade cada vez maior de levar o conhecimento para fora dos muros acadêmicos (Albagli, 1996). 
Enquanto no passado a imagem científica ficava restrita a pinturas e ilustrações científicas, a fotografia hoje abre um campo muito grande para ser explorado. Os celulares com câmeras cada vez melhores permitem, por exemplo, a captação de imagens de microscopia com uma facilidade que até então não existia. Porém não basta apenas a tecnologia avançar e termos cada vez mais equipamentos capazes de registrar boas fotografias. É necessário que o meio acadêmico valorize e reconheça o potencial da fotografia como ferramenta de pesquisa e de divulgação científica e, ao mesmo tempo, que se aproprie deste conhecimento. O que vemos na prática, na maioria das vezes, são livros, trabalhos de pós-graduação e textos científicos com muito poucos registros fotográficos de qualidade. É comum vermos livros que se destinam a serem guias de identificação de espécies baseados em imagens fotográficas, nos quais as imagens são de péssima qualidade e não servem ao seu propósito. Orientadores de pós-graduação que incentivam seus alunos a não colocarem imagens em seus trabalhos e revistas científicas que restringem cada vez mais a publicação de imagens. Isto se deve muitas vezes ao desconhecimento do potencial comunicativo da imagem. Uma imagem pode contribuir com um trabalho científico da mesma forma que um gráfico ou uma tabela. Basta ser pensada e dirigida para tal fim.

No ensino ocorre algo semelhante. Embora praticamente todos os alunos hoje tenham um celular em mãos, poucos são os professores que sabem utilizar este aparelho como recurso didático. Para Mota (2014), o papel da educação nos dias atuais é o de propiciar a construção de estruturas cognitivas que suportem procedimentos necessários para atuar no mundo contemporâneo e a imagem faz parte, de maneira inegável, do mundo contemporâneo. A educação hoje requer estratégias que extrapolem as fronteiras do ensino formal e a fotografia, assim como outras ferramentas, tem este potencial. Porém é necessária capacitação para que os professores compreendam a amplitude de possibilidades da utilização da fotografia no ensino. 
Conclui-se que a fotografia tem um grande potencial de utilização como ferramenta de ensino e divulgação científica, porém carece de incentivo, valorização e discussão sobre a forma de utilizá-la. Iniciativas como a criação desta revista científica são fundamentais para alcançar estes objetivos e trarão grandes frutos.

\section{REFERÊNCIAS}

Albagli S. 1996. Divulgação científica: informação científica para a cidadania? Ciência da Informação. 25(3): 396-404.

Borges MEL. 2003. História \& Fotografia. Belo Horizonte (MG): Autêntica. 136 p.

Hacking J. 2012. Tudo sobre fotografia. Rio de Janeiro (RJ): Editora Sextante. 576 p.

Mota R. 2014. Inovação e aprendizagem independente na educação básica. Ciência e Natura. 36: 121-129.

Sontag S. 1986. Ensaios sobre Fotografia. Lisboa: Publicações Dom Quixote. 178p. 